\title{
Millennium Development Goals in Europe
}

\author{
Anne Marie Oudesluys-Murphy
}

- Additional material is published online only. To view please visit the journal online (http://dx.doi.org/10.1136/ archdischild-2013-305871).

\section{Correspondence to}

Professor Anne Marie Oudesluys-Murphy, Willem Alexander Children's Hospital, Leiden University Medical Centre, Leiden 2333 ZA, The Netherlands;

h.m.oudesluys-murphy@lumc. $\mathrm{nl}$

Received 25 July 2014 Revised 14 October 2014 Accepted 15 October 2014

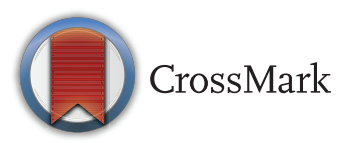

To cite: OudesluysMurphy AM. Arch Dis Child 2015;100(Suppl 1):s72-s73.

\section{INTRODUCTION AND BACKGROUND}

Although the term 'Europe' is regularly taken to include only the 28 countries of the European Union (often expanded to include Norway and Switzerland), the European region of WHO comprises 53 countries, home to nearly 900 million people (table 1). The countries vary in size, languages, political systems, economic situations and cultural backgrounds. WHO information on the region is included in reports on the UNECE region (United Nations Economic Commission for Europe) or incorporated in the group of highincome countries. ${ }^{12}$

Western European countries and early members of the European Union have had the advantage of relatively long political stability, established health systems and well educated more affluent populations. They have been at the forefront in innovative research and development in all fields, especially in health topics, leading to many improvements for their own populations. Though many aspire to the standards of living, welfare and health of the Nordic countries there is, and always has been, inequity in health and wealth between and within European countries. The affluence and accessibility of many of these countries has led to mass influxes of migrants and asylum seekers, including children. However, many host countries are unable to offer the care and support needed. Due to recent economic crises many health gains have been lost. Some WHO European Member States now need WHO's assistance themselves for health systems reforms.

\section{OVERVIEW MILLENNIUM DEVELOPMENT GOALS (MDGS)}

\section{MDGs strongly affecting children}

MDG 1: Eradicate extreme poverty and hunger

Almost 27 million children in Europe are at risk of poverty or social exclusion (see online supplementary table). Even in European Union member states, children are more vulnerable to poverty than the rest of the population with 19\% of children living under the threat of poverty. The financial and economic crisis that started in 2008 has severely affected children and their families by hitting employment and welfare systems. In the central and eastern areas of the region much has changed since the collapse of the old Soviet Union and many of these countries have not caught up easily. A small minority became very wealthy quickly but many people are worse off than before. The old regime allowed full employment, a minimum income with child cash benefits, free health care and education for many families. ${ }^{1}$ However, since 1999 nearly 90 million of the 480 million people in eastern Europe and central Asia (about 18\% of the population) have moved out of poverty and vulnerability. ${ }^{3}$
In the report 'Child well-being in rich countries' (2013), the relative child poverty rate (percentage of children living below the nation's poverty line) is lowest $(4 \%)$ in Finland. ${ }^{4}$ The child poverty gap (the distance between the poverty line and the median incomes for those below the line) is smallest in Luxemburg and Hungary (just over 10\%) but it has widened to more than $30 \%$ in several countries, including Bulgaria, Ireland and Italy. In Spain $20 \%$ or more children fall below the relative poverty line and on average they fall almost $40 \%$ below that line. In Austria and The Netherlands $6-8 \%$ fall below the relative poverty line and on average $16 \%$ below. Among the countries in this report, children's material wellbeing is rated as highest in The Netherlands and lowest in Romania.

Poverty means not only that children's basic needs, such as food, clothes and adequate housing, might not be met. It is linked to social exclusion and lack of access to services, including health care, child care and high-quality education. These effects can last a lifetime and be felt in future generations.

\section{MDG 4: Reduce child mortality}

In addition to infant mortality, the under-five mortality rates are dropping across the European region (from 26 to 10 per 1000 live births between 1990 and 2012). However, the decline is less steep than in 1975-1990, with marked variations between countries, for example, under-five mortality rates of 1 in The Netherlands, 4 in the UK and 26 per 1000 live births in Uzbekistan. ${ }^{2}$ The high average immunisation rates achieved in many countries are falling in some, exacerbated by activities of antiimmunisation lobby groups and fears of complications (often based on inaccurate scientific reports). ${ }^{2}$

\section{MDG 5: Improve maternal health}

Child health is closely related to, and to a large extent dependant on, maternal health. Over the whole region the maternal mortality rate has dropped from 42 to 17 deaths per 100000 live births between 1990 and 2013. The risk of dying from causes related to pregnancy and childbirth differs greatly across the region, depending on where mothers live, with maternal mortality rates of 4 in Finland and 75 (per 100000 live births) in Kyrgyzstan. $^{2}$

\section{MDG 6: Combat HIVIAIDS, malaria and other diseases (including tuberculosis)}

Since 2010 paediatric HIV/AIDS has decreased by $10 \%$ in the European region, mainly due to a decrease in western countries, even though $75 \%$ of infected children were in the east. Mother to child transmission accounted for just $1 \%$ of new cases of paediatric HIV/AIDS reported in 2012. Almost 
Table 1 Countries in the WHO European region

\begin{tabular}{lll}
\hline Albania & Germany & Poland \\
Andorra & Greece & Portugal \\
Armenia & Hungary & Republic of Moldova \\
Austria & Iceland & Romania \\
Azerbaijan & Ireland & Russian Federation \\
Belarus & Israel & San Marino \\
Belgium & Italy & Serbia \\
Bosnia and Herzegovina & Kazakhstan & Slovakia \\
Bulgaria & Kyrgyzstan & Slovenia \\
Croatia & Latvia & Spain \\
Cyprus & Lithuania & Sweden \\
Czech Republic & Luxembourg & Switzerland \\
Denmark & Malta & Tajikistan \\
Estonia & Monaco & The former Yugoslav Republic \\
Finland & Montenegro & of Macedonia \\
France & Netherlands & Turkey \\
Georgia & Norway & Turkmenistan \\
& & Ukraine \\
& & UK \\
& & Uzbekistan \\
\hline
\end{tabular}

$70 \%$ of all pregnant women were tested and knew their HIV status in 2011, over 95\% of HIV-infected pregnant women had access to antiretroviral therapy and more than $95 \%$ of infants of women who were HIV-positive were tested within 2 months of birth. However there are still pregnant women who inject drugs, are sex workers, migrants, prisoners, or have partners at high risk of HIV infection who do not have access to antenatal care or present too late for consultation or treatment. ${ }^{5}$

Tuberculosis (TB) is still an important problem in the European region. During 2006-2010 TB notification in children (0-14 years) decreased by $10 \%$ from 7.0 to 6.3 cases per 100000 population but in 20 of the region's countries children represented more than 5\% of all TB cases. Poor adherence to control practices has created high levels of multidrug-resistant TB (MDR-TB) and extensively drug-resistant TB. Of the 27 countries globally responsible for most MDR-TB cases, 15 are in the European region. ${ }^{3}$
MDG 2: Achieve universal primary education

Almost all children in the European region finish primary education and are literate. However, just being able to read and write is not enough in today's world. Populations living in poverty and ethnic, linguistic and religious minorities, and children with disabilities have fewer educational opportunities and will be unable to move out of poverty. ${ }^{2}$

\section{CONCLUSION}

Every year 10.7 million babies are born in the WHO European region. However, these children do not all have the same chances. The social, educational and economic backgrounds of earlier generations all influence how they progress through life. A child born today in a high-income European country can expect to live, on average, 19 years longer than a child born in a low-income country. ${ }^{3}$ Paediatricians are aware of the social, economic and cultural factors affecting the health of children. However, problems seen in hospitalbased curative care reflect only the tip of the iceberg and the best hospital care in the world cannot make these problems go away for ever. However, all paediatricians can play an important role in improving the physical and mental health of children and can attempt to influence political decision-making on these questions.

Competing interests None.

Provenance and peer review Commissioned; internally peer reviewed.

\section{REFERENCES}

1 The MDGs in Europe and Central Asia. Achievements, challenges and the way forward. http://www.unece.org/fileadmin/DAM/commission/MDGs/2010_MDG_ Optimized.pdf (accessed Jul 2014).

2 World Health Statistics. 2014. http://apps.who.int/iris/bitstream/10665/112738/1/ 9789240692671 eng.pdf (accessed Jul 2014).

3 Millennium Development Goals in the WHO European Region. A situational analysis at the eve of the five-year countdown. Copenhagen: WHO Regional Office for Europe, 2010. ISBN: 978928904202 4. http://www.euro.who.int/_data/assets/ pdf_file/0006/95595/E93723.pdf (accessed Jul 2014).

4 Child Well-being in Rich Countries. A comparative overview. Innocenti Report Card 11. Florence: UNICEF Office of Research, 2013. http://www.unicef.org/media/files/ RC11-ENG-embargo.pdf (accessed Sep 2014).

5 AIDS/HIV. http://www.euro.who.int/en/health-topics/communicable-iseases/hivaids/news/ news/2014/07/hivaids-epidemic-in-europe-mother-to-child-transmission (accessed Sep 2014) 